\title{
Career Development Opportunity Cures for the Impairment Effect of Careerist Orientation on Organizational Citizenship Behaviours: Empirical Evidences form Project Based Employees Working in Non-profit Making Organization
}

\author{
Ganesh Bhattarai ${ }^{1}$, Dhruba Raj Pokharel, $\mathrm{PhD}^{2}$, and Prem Bahadur Budhathoki ${ }^{3}$ \\ ${ }^{1}$ Principal author \\ Lecturer
}

Faculty of Management, Nepal Commerce Campus, Kathmandu, Tribhuvan University, Nepal

${ }^{2}$ Corresponding author

Associate Professor

Faculty of Management, Nepal Commerce Campus, Kathmandu, Tribhuvan University, Nepal

${ }^{3}$ Co-author

Lecturer

Faculty of Management, Mahendra Multiple Campus, Dharan, Tribhuvan University, Nepal

Email: ${ }^{1}$ ganesh@ncc.edu.np, ORCID: 0000-0001-9163-5172² dhruba@ncc.edu.np

3 prem.budhathoki@mahmc.tu.edu.np, ORCID: 0000-0002-1249-7005

DOI: https://doi.org/10.3126/dristikon.v10i1.34545

\begin{abstract}
This study was carried out to examine the direct impact of employees' careerist orientation and career growth opportunities on their organizational citizenship behaviours (conscientiousness and altruism) as well as role of career growth opportunities in the relationship between careerist orientation and organizational citizenship behaviours (conscientiousness and altruism). 268 employees working in non-profit making projects in Kathmandu valley were surveyed and analyzed. Quantitative analysis of multi-source measured perceptual data revealed that (1) employees' careerist orientation negatively impacts on organizational citizenship behaviour (conscientiousness and altruism), (2) and career growth opportunities positively impacts on organizational citizenship behaviours (conscientiousness and altruism), and (3) employees career growth opportunities cure their harmful impact of careerist orientation on organizational citizenship behaviour (conscientiousness and altruism). Moreover, this study tested the different forms (effect sizes) of interactive effect of employees' careerist orientation and career growth opportunities to predict their organizational citizenship behaviours (conscientiousness and altruism). For example, it was tested that a relatively strong marginal negative prediction of careerist orientation on organizational citizenship behaviours (conscientiousness and altruism) was for those employees who perceive a low level of career growth opportunities. A number of theoretical and practical implications are suggested.
\end{abstract}


Keywords: Careerist orientation, career growth opportunities, organizational citizenship behaviours, conscientiousness, altruism

\section{Introduction}

\section{Background of the Study}

Employees' efforts for non-performance-based means to pursue their career advancement is the careerist orientation (Feldman \& Weitz, 1991). Careerist oriented employees believe that merit alone is not enough for achieving upward mobility in organizations, thus they often focus more upon image building than hard work (Bolino, 1999). Strategic refocusing, business reengineering, and downsizing in times of financial crunch have become common events in the face of ever-increasing global competition (Sullivan \& Baruch, 2009). Due to increased global competition, many organizations in both the developed and underdeveloped countries have to operate in an increasingly turbulent economic environment. Consequently, organizations are forced to adopt strategic actions as downsizing, delayering, reengineering etc. in order to cut down costs and to boost up productivity. Such circumstances and actions, to cope up with the situations, lead the labor market as volatile with economic, social and psychological distress to the employees. Subsequently, employees start to think about their own career management, not for an organization, as careerist-oriented employees. One of the central beliefs of careerist orientation is that in the long run the individual career goals and the organization's goals for the individual are inconsistent and so, the individual has to look out for their own interests (Feldman \& Weitz, 1991). This is because the perceived incompatibility of personal and organizational goals suggests that individuals would have to take care of themselves. Contemporary careerist orientation has developed from lessened job security and more arbitrary and unpredictable treatment of employees by the organization (Feldman, 1985). One of the sources of competitive advantage in 21th century is employees and if they do focus on their own career management than an organization, it is a serious issue for organization to achieve competitive advantage. Hence, searching remedies for proper intervention to tackle employees' careerist orientation seems most for both academician and practicing managers.

Careerist oriented employees believe that performance alone does not ensure their career progress and they focus on network building and impression management (Bolino, 1999) for their career management therefore careerist orientation impacts negatively on employees' organizational citizenship behaviours. Organizational citizenship behaviours refer to employees' those behaviours that are discretionary and not recognized by the reward system in the organization (Organ, 1988). Written contract and job description do not cover every single responsibility of the employees, beyond the written documents, employees have to do many things that the situation demands. Employees should/and or do help to the organization and other members of the organization that are not officially assigned. Employees' citizenship 
behaviours enhance employee's attitudinal and behavioral outcomes that are essential for organizational success. Podsakoff et al. (2009) verified in their meta-analysis that organizational citizenship behaviours were related to important individual outcomes such as employee performance, absenteeism, and turnover, and to organizational outcomes such as cost reduction and customer satisfaction. Therefore, it is necessary to know the antidotes for the harmful effect of employees' careerist orientation on their organizational citizenship behaviours for practicing managers as well as academicians.

A career growth opportunity is the most determinant for employees' career choice and its continuity (Wang et al., 2014) in working life. If employees see the better career development opportunities, it is normal that they try to do beyond the formal roles (discretionary behaviours) for the organizations to grab the targeted career goals. Such efforts might be stronger even for those employees who are careerist oriented, because their eagerness for career advancement insists to do better for an organization where they see inbuilt own benefits. Social cognitive career theory (Lent et al., 1994) suggests a significant foundation for the relationship between individual differences and organizational career opportunities. Vande Griek (2018) states individual characteristics of employees determine the degree of benefits from career growth opportunities on their career advancement. Career growth opportunities do knots between employees and employers (Wang et al., 2014) to do work for mutual benefits for a long time. Therefore, we raised the question that does employees' perceived career growth opportunities play role as a remedy for the detrimental effect of their careerist orientation on organizational citizenship behaviours (conscientiousness and altruism).

In this context current study was motivated know how employees careerist orientation is associated with their organizational citizenship behaviours (conscientiousness and altruism) and to know whether employees' perceived career growth opportunities attenuate the destructive impact of careerist orientation on their organizational citizenship behaviors (conscientiousness and altruism) or not. To answer these questions, the current study was dedicated to know the impact of careerist orientation on employees' citizenship behaviours (conscientiousness and altruism) and role of perceived career growth opportunities in stated relationship in the context of employees working on Nepalese development projects.

\section{Review of Literature}

\section{Careerist Orientation}

To describe the attitudinal response of the individualistic people the concept of careerist orientation was originally used while transferring employment relationship from relational to transactional psychological contract (Chay \& Aryee, 1999). Technological advancement, organizational reengineering, downsizing, financial crunch, global competition made the workplace more competitive and volatile; to cope up with such circumstance 
employees engage themselves for managing their career. Such engagement of employees in their own career management minimizes the focus of employees for organization. Aryee and Chen (2004) states career attitude that has emerged is "careerist orientation" wherein the employees believe that getting ahead in one's career can be best accomplished by nonperformance means

Feldman and Weitz (1991) describe numbers of assumptions for achieving one's career advancement like: (1) hard work or merit alone is not sufficient for career advancement, (2) to get career success, good relationships with superiors, co-workers, and friends are necessary, (2) necessary to show appearance of being successful, because appearing successful can be important as competence itself, (4) it is true that in the long run, employees' career goals will be inconsistent with the interests of the organization, (5) it is true, faithfulness to an employer is questionable to be rewarded, (6) to get even deserving promotion, occasionally, it is essential to involve in deceptive behavior, and (7) Sometimes, to get career achievement, it is necessary to take actions for personal benefit rather than those organizational interest. These assumptions were rooted as a foundation for the study of employees' careerist orientation in their work place.

Employees displaying careerist orientation believe that they have to look out for their personal interests and not rely on the possible achievement of a long-term career planning, if any, proposed by the employer. Turnley and Feldman (1999) states employees demonstrating careerist orientation place less value in the employment relationship. Employees with a high careerist orientation would typically not believe that either the organization or the employees owe anything to one another and so, there is less likelihood of performing the behavior above the normal role expectations.

\section{Organizational Citizenship Behaviours}

Employees' behaviours in organizations that are discretionary and not directly or explicitly recognized by the organization in contract and reward system is the organizational citizenship Behaviours (Organ, 1988). Moreover, Bateman and Organ (1983) suggested the conception of organizational citizenship behaviors to denote those organizationally beneficial behaviors and gestures that are neither enforced on the basis of formal role obligations nor elicited by contractual compensation. Employees' discretionary behaviours are those roles that are not planned, not predetermined, not even expected, and not mentioned somewhere in their reward system, but are very important aspects of the organization for its effective functioning. For example, participation in unscheduled business meeting in odd hours, advocating and supporting for the organization and its product in informal discussion or in chitchat, helping other coworkers when they are in need. Organizational citizenship behaviours are extra role behaviour as promoted by transformational leadership. 
Lo and Ramayah (2009) state the lack of consensus about the dimensions of organizational citizenship behaviours, though it is more important for the organization. Moreover, Podsakoff et al. (2000) mentioned that there are around 30 dimensions of organizational citizenship behaviours and are categorized into seven groups like helping behaviours, sportsmanship, organizational loyalty, organizational compliance, individual initiative, civic virtue, and self-development. Likewise, Organ (1988) has acknowledged five dimensions of the organizational citizenship behaviours: (1) altruism, (2) conscientiousness, (3) civic virtue, (4) sportsmanship, and (5) Courtesy. Beside the disagreement for the dimensions of organizational citizenship behaviours, current study has taken into consideration Organ's two dimensions i.e. conscientiousness and altruism. This is because, firstly, these behavioral dimensions have yet to be differentiated from one another in the empirical literature, even though many scholars have claimed that organizational citizenship behaviours are composed of conceptually distinct behavioral dimensions (LePine et al., 2002); secondly, in development projects, project time is short and objectives are humanitarian support where employees' conscientiousness and altruism behaviours are most important. Altruism is about employees' discretionary behaviors that have the effect of helping a specific other person with an organizationally relevant task or problem (Podsakoff et al., 1990). Likewise, conscientiousness denotes the discretionary behaviors on the part of the employees that go well beyond the minimum role requirements of the organization, in the areas of attendance, obeying rules and regulations, taking breaks, and so forth (Podsakoff et al., 1990).

\section{Career Growth Opportunities}

Organizational career growth refers to the extent to which an individual perceives that the employing organization provides an environment where his or her career goals can be attained (Weng et al., 2010). Employees may perceive their career growth opportunities if there are adequate career goal progress, opportunities of promotion and remuneration growth, and chances of development of professional ability in their organization (Weng \& McElroy, 2012; Weng \& Hu, 2009). Adequate career goal progress specifies the situation where employees' working organization ensures them to achieve their career goals. Development of professional ability denotes the situation where employees' current organization ensures them to increase sufficient skill, diversified knowledge, and wide range of experience that enhance their career related competences. In the same way, an opportunity for promotion and remuneration growth specifies the conditions where employees are capable to get higher positions as per their abilities and receive a salary increase in their current organization.

Weng and $\mathrm{Xi}$ (2010) stated that career development over an employee's total work life is progressively autonomous of long-term organizational outcomes, because of more frequent unpredictable paths of careers and more frequent job changes. Employees' career growth in an organization is closely knotted to individual attitudes and outcomes within the employees' 
current organization (Wang et al., 2014). Therefore, Organizational career growth is an important component of the employee-employer relationship and becomes the predictor of the organizational citizenship behaviours. Hence, perception of career growth opportunities in their current organization makes them to be obligated to exhibit conscientiousness and altruism.

\section{Careerist Orientation and Organizational Citizenship Behaviours}

Employees who perceive high promotional opportunities in their organization have higher levels of organizational commitment (Alvi \& Ahmed,1987), personal development opportunity (Liu \& Wang, 2001), promotion equity and training (Long et al., 2002), and opportunity for learning ( $\mathrm{Ng}$ et al., 2006). But careerist orientation was negatively associated with job satisfaction, job involvement, organizational commitment, and work motivation (Feldman \& Weitz, 1991). Similarly, Chay and Aryee (1999) tested careerist orientation to be negatively related to job involvement and organizational commitment, but positively to turnover intention. Here empirical evidences verified that employees' careerist orientation were detrimental for the employees' behavioral and attitudinal outcomes, therefore, it is postulated that increment of such behaviour negatively impacts on their organizational citizenship behaviours (conscientiousness and altruism).

As explained by social exchange theory (Balu, 1964), employees who are highly careerist oriented, they do not think for a long-term perspective of their working relationship with the organization, consequently they are less likely to exhibit their conscientiousness and altruism behaviour. Employees having high careerist orientation concentrate on their nonperformance means using Machiavellian tactics for career advancement and they don't see the meaning to go beyond their formal contract and reward system, consequently, deteriorates their conscientiousness and altruism behaviour. Furthermore, careerist orientation alerts employees to uninteresting employment which may result in withdrawal behaviors (Feldman \& Weitz, 1991) instead of engaging on conscientiousness and altruism behaviour. Therefore, we hypothesized the following Hypothesis

Hypothesis1.A: Employees careerist orientation negatively impacts on their (A) conscientiousness behaviour, and (B) altruism behaviour. This means an increase (or decrease) on employees' level of careerist orientation cause to decrease (or increase) in their level of conscientiousness and/or altruism behaviours.

\section{Career Growth Opportunities and Organizational Citizenship Behaviours}

Relationship between job attitudes and organizational citizenship behaviours are theoretically based on social exchange theory (Konovsky \& Pugh, 1994). Employees who are fine with their work environment, in terms of career advancement, are to be expected to interchange by offering a benefit to the organization through extra-role behaviors which are not mandatory in their formal contract like engagement in organizational citizenship behaviours. 
Employee who does not see career development opportunities within their current organization they might exhibit withdrawal behaviour from the organization, but if they see the opportunities for career growth it is natural that they put extra efforts and behaviours for the betterment of the organization. These mean employees who perceive their organization as a good platform for their career growth they work positively for their organization devoting formal as well as informal efforts. Scholars Weng and McElroy (2012), and Weng et al. (2010) confirmed that employees experiencing high levels of career growth within their current employment express more organizational commitment and less intention to leave. Based on these theoretical arguments as well as empirical evidences we believe that employees' perceived career growth opportunities encourage them to do discretionary roles like conscientiousness and altruism. Therefore, we hypothesized the following hypothesis.

Hypothesis 2. A: Employees perceived career growth opportunities positively impacts on their (A) conscientiousness behaviour, and (B) altruism behaviour. This an means increase (or decrease) on employees' perceived career growth opportunities cause to decrease (or increase) in their level of conscientiousness and/or altruism behaviours.

\section{Interactive Effect of Careerist Orientation and Career Growth Opportunities on Organizational Citizenship Behaviours}

In the previous section, we reviewed that employees' careerist orientation negatively impacts on employees' organizational citizenship behaviours (conscientiousness and altruism) because they believe performance and formal procedure are not sufficient for their career advancement in an organization. But such relationship might be altered due to personal factors of the employees. Van et al. (1994) claimed that a number of individual and contextual factors influence citizenship behavior through the mediating role of a covenantal relationship. Likewise, Konovsky and Pugh's (1994) tested the importance of justice in the relationship of citizenship behavior to trust. Moreover, we also discussed that if employees perceive high career growth opportunities in their organization, such perception positively impacts on employees extra role behaviour like organizational citizenship behaviours (conscientiousness and altruism). Hence, we assumed that there is the possibility of interactive effects of careerist orientation and career growth opportunities on organizational citizenship behaviours. The detrimental effect of careerist orientation on conscientiousness and altruism will be dampened due to employees perceived career growth opportunities. Consequently, we hypothesized the following hypothesis:

Hypothesis 3: Employees career growth opportunity moderates the relationship between their: (A) careerist orientation and conscientiousness behaviour, and (B) careerist orientation and altruism behaviour. This mean direct impact of employees' careerist orientation on their conscientiousness and altruism behaviors modifies due to the level of their perceived career growth opportunities in current job or organization. 
Especially, if employees see the good career growth opportunities in their current job/ or organization, their conscientiousness and/or altruism behaviours will be better than employees who don't see the chances.

\section{Methods and Materials}

\section{Research Design and its Rationale}

Positivist research philosophy and quantitative research design has been followed to analyze the perceptual data. Quantitative research is typically considered to be the more scientific approach to do social science research (Richard, 2009). Indeed, the ability to make correct predictions are one of the most outstanding characteristics of quantitative methodology and it may be valuable for evaluating theory and testing whether the theory holds up under a variety of circumstances and instances.

\section{Measures}

\section{Careerist Orientation}

Careerist orientation was measured by nine-item measure developed by Feldman and Weitz (1991). This scale gauged the extent to which individuals agree that advancement in organizations is based more on image management and personal connections than on competence (Feldman et al., 2002). A sample item is: the key to success is who you know, not what you know. Respondents have been asked to report how much they agreed with the items on a scale from 1 (strongly disagree) to 5 (strongly agree). The coefficient alpha of the careerist orientation in the current study was .83

\section{Career Growth Opportunities'}

A career growth opportunity was measured by using a five-point scale of Nouri and Parker (2013). This scale was initially developed by Bedeian, Kemery, and Pizzolatto (1991) with two items and updated by Chay and Aryee (1999) adding two more items. Few sample items include: (1) I feel that my present job will lead to the future attainment of my career goals, (2) My present job is relevant to the growth and development in my career. The coefficient alpha of the construct in the current study was .75.

\section{Conscientiousness}

Conscientiousness was measured using five items measure developed by Podsakoff et al., (1990). Conscientiousness items were measured in five-point Likert type scale ranging from 1 (strongly disagree) to 5 (strongly agree). Sample items include: (1) obeys company rules and regulations even when no one is watching, (2) is one of the most my conscientiousness employees. The coefficient alpha of the construct conscientiousness in the current study was 76 . 


\section{Altruism}

Podsakoff et al.'s (1990) five item scale was used to measure the altruism of the employees. All items of the altruism were measured in five-point scale ranging from 1 (strongly disagree) to 5 (strongly agree). Sample items include: (1) helps orient new people even though it is not required, (2) willingly helps others who have work related problems. The coefficient alpha of the construct altruism in the current study was .79

\section{Demographic Variables}

As the control variable, demographic variables like gender, experience, and education of the employees were included as control variables in the current study. Such demographic variables may be associated with the independent, dependent, and moderating variables, therefore were controlled while employing regression analysis.

Sampling Procedure and Respondents

Employees working in the development projects run by the non-government organization (NGO) were selected as the population of the study. To select the sample, first of all, Kathmandu based NGOs (head office in Kathmandu, but their projects might be outside the Kathmandu valley) were listed out as per the official record of the Social Welfare Council (SWC) Nepal. Then, as per the convenience of the researchers' 15 NGOs were selected representing diversity in their working area like health, disaster response, mental health, gender equality, women and children, disability etc. from the listed-out NGOs. Within the listed-out NGOs, around 400 employees working on various projects under the different NGOs were identified as respondent as per the convenience of researchers.

Administration of the Questionnaire

Two sets of questionnaires were prepared (Sat-A and Set-B). Set-A was prepared to measure the employees' conscientiousness and altruism behaviour by their supervisor. In SetA questionnaire, supervisors were asked to write the name of the subordinate and evaluate them based on the given statements. Set-A questionnaire comprised the 10 items beside the name of the subordinates. Set-B was prepared to measure the employees' careerist orientation and career growth opportunities by concerned employees themselves. In Set-B questionnaire, employees were asked to write their own name and evaluate own-self based on given statements. Set-B questionnaire comprised the 22 items including demographic variables. In both sets of questionnaires, name of the respondents/subordinates were requested for the purpose of matching questionnaire evaluated for (by supervisor) and by (own-self) a particular respondent. Except the demographic details, perceptual responses for all items (in Set-A and Set-B) have been obtained in a 5-point Likert-type scale. Both sets of questionnaires were prepared in English language. Five people comparable to the respondents of this research also checked the language, simplicity, and clarity of the questionnaire before finalizing the 
questionnaire. For the administration of questionnaires, executive director/or office in charge of each and every sample selected NGOs were requested to make participate their employees in the survey process. In each NGOs, on the request of the researchers, a referral person was assigned by executive director/or office in charge to facilitate the distribution and collection of the questionnaires. Researchers explained to the assigned reference person in each NGOs regarding the questionnaire fill up and return back procedure, and respondents' anonymity. Among the identified respondents, 370 pair of set of questionnaires was distributed as per the convenience of the researchers. Out of distributed questionnaire, only $291(78.65 \%)$ set of pairmatched questionnaire were returned back. Again, out of returned back questionnaire, 268 (72.43\% of distributed questionnaire) sets were retained for analysis.

The internal validity of this research has been ensured through measuring different constructs using prior validated measures. Hypotheses were formulated based on the comprehensive review of the empirical evidence from the different context. The normality of the data was tested by plotting Histogram and Normal Q-Q plot and found normally distributed. Variance Inflating Factor (VIF) was tested and found less than 10, which is not problematic (Adnan et al., 2006).

\section{Common Method Variance}

As suggested by Podsakoff et al. (2003), researchers have implemented three essential strategies to avoid the problem of common method bias like (1) predictor variable and dependent variables were collected from different sources. Independent variable careerist orientation and moderating variable career growth opportunities were rated by respondent themselves but dependent variables conscientiousness and altruism were rated by respondent's immediate supervisors, (2) around 33\% ( eight items) questionnaire were reverse scored to reduce the potential effects of response pattern biases, by incorporating negatively worded items in the questionnaire, and (3) questions measuring different variables (e.g. independent, moderating, and dependent) were offset in order, so that respondents could not recognize the corresponding constructs of the items.

Alongside these remedial measures, to know the degree of common method bias, the current study has tested the Harman's one-factor test, which implements principal component factor analysis of all the variables in the model. According to Podsakoff et al. (2003), one of the most widely used techniques that has been used by researchers to measure the problem of common method variance is Harman's one-factor (or single-factor) test. Researchers may conclude that the bias is serious when the analysis (from Harman's one-factor test) retains only one factor or a single factor explains most covariance (Podsakoff, et al., 2003). In the current study, the analysis revealed that four factor model explained only $23.36 \%$ of the variance when it is loaded on a single factor. If the single factor explains less than $50 \%$ of the variance, then 
result shows that the bias is not so serious as to make analysis invalid even though it may still slightly inflate or deflate regression coefficients (Cho \& Lee, 2012).

\section{Data Analysis}

Data were refined and analysed employing the Statistical Package for Social Sciences (SPSS) version 23 as well as micro-soft excel. The perceptual data collected for the current study were analysed in various phases. Firstly, to determine the item retention in the context of current study, factor analysis (principal component analysis with varimax rotation) was computed on all multiple scale items. In order to avoid confounded measures of closely related constructs, the following three strict rules-of-thumb have been applied. The Items were retained only; i) with a strong loading of .50 or higher (Nunnally \& Bernstein, 2007), ii) a cross-loading of less than .35 on other included factors (Kiffin- petersen \& Cordery, 2003), and iii) a differential of .20 or higher between included two or more factors (Van Dyne et al., 1994). In the case of rephrasing and contextualizing construct items, researchers (e.g. Karatepe, 2012; Dysvik \& Kuvaas, 2012) prefer exploratory factor analysis than confirmatory factor analysis. All the items used in the current study were prepared in English with rephrasing and contextualizing as per the research context that is why exploratory factor analysis has been adopted rather than confirmatory factor analysis. After confirmatory factor analysis, Cronbach alpha for each and every constructs were measured to ensure the reliability of the construct.

Histogram and Normal Q-Q plot were plotted to test normality of the residual. Multicollinearity diagnostic was tested (by VIFs) to measure the multicollinearity between the careerist orientation and career growth opportunities while measuring the interactive effect of careerist orientation and career growth opportunities on the conscientiousness and altruism behaviours.

Pearson correlations have been calculated to identify the simple relationships between the study variables. Likewise, Hierarchical Regression Models (MRM) have been computed to measure significant of direct as well as interactive association of the employees' careerist orientation with their conscientiousness and altruism behaviours after controlling the effect of demographic variables (e.g. age, sex, education, experience etc.). In Hierarchical Regression Models (HRM), guidelines of Baron and Kenny (1986) have been employed to measure the moderating effect of career growth opportunities in the relationship of careerist orientation with conscientiousness and altruism. Change in $\mathrm{R}^{2}$ has been used to measure the significance of adding another variable in a model. Micro-soft excel was used for graphic presentation of the interactive relationship of the careerist orientation and career growth opportunities on conscientiousness and altruism behaviours, because graphic presentation more clarifies the role of moderating variable in the relationship between independent variable and dependent variable (Jose, 2008). 


\section{Results and Discussion}

Principal component analysis revealed that two items of the careerist orientation cross loaded in another excluded factor, two factors were loaded less than .50 threshold value. Remaining five items, out of the nine items, were loaded on a single factor and these items were considered to measure the construct 'careerist orientation'. Out of five items of a construct 'career growth opportunities, one items were cross loaded in other excluded factor and remaining four factors were loaded properly. One item of the altruism was loaded in another included factor and remaining four items were loaded properly. All the items of the construct conscientiousness were loaded properly in a single factor. Therefore, all the constructs were calculated after removing the items which were not loaded properly in the corresponding factors. Details of principal component analysis have been presented in Ann. 1.

Relationships between study variables with each other were statistically significant with correlation coefficients ranging within -.16 to .64. Directions of the relationship between tested variables were measured as hypothesized. As depicted in Table 1, there were no strong (all are less than .80) correlation coefficients between predictor variables; therefore, there were no significant problems of the multicollinearity.

\section{Table 1}

Pearson's Correlations, Mean and Standard Deviation of the Study Variables

\begin{tabular}{lcccccc}
\hline \multicolumn{1}{c}{ Variables } & Mean & $\begin{array}{c}\text { Std. } \\
\text { dev. }\end{array}$ & 1 & 2 & 3 & 4 \\
\hline 1) Careerist orientation & 3.42 & .78 & & & \\
2) Career growth opportunities & 2.70 & .84 & $.27^{* *}$ & & \\
3) Conscientiousness & 2.84 & .83 & $-.27^{* *}$ & $.40^{* *}$ & \\
4) Altruism & 3.12 & .89 & $-.16^{* *}$ & $.43^{* *}$ & $.64^{* *}$ & \\
\hline
\end{tabular}

Note. $* *$. Correlation is significant at the 0.01 level (2-tailed).

However, VIFs (variance-inflating factors) have been calculated to measure the presence (or not) of the multicollinearity while calculating the interactive effect of careerist orientation and career growth opportunities while calculating hierarchical regression model. In the current study, VIFs have been found less than 10 except interactive variables. According to Adnan et al. (2006), the multicollinearity would not be problematic if VIF is less than 10. Paul (2012) states, even VIFs are more than 10 and it is caused by the inclusion of power or product (due to the interaction of careerist orientation and career growth opportunities in the current study) of two or more variables, there would not be a problem of the multicollinearity. 
As shown in Table 2, Step 2, after controlling the effect of demographic variables, coefficient of careerist orientation to predict conscientiousness was negative and statistically significant $\left(B=-.28, \mathrm{p}<.01, \Delta \mathrm{R}^{2}=.07\right)$. Therefore, hypothesis 1.A was supported with contributing additional $7 \%$ variance in the model. Similarly, to predict altruism, coefficient of the careerist orientation after controlling the effect of demographic variable was negative and statistically significant $\left(B=-.19, \mathrm{p}<.01, \Delta \mathrm{R}^{2}=.03\right)$. Hence, hypothesis $1 . \mathrm{B}$ was supported with contributing additional 3\% variation in the model. As depicted in Table 2, Step 3, after controlling the effect of demographic variables and careerist orientation, coefficient of the career growth opportunities to predict conscientiousness was positive and statistically significant $\left(B=.53, \mathrm{p}<.01, \Delta \mathrm{R}^{2}=.27\right)$. Therefore, hypothesis 2 .A was supported with contributing additional $27 \%$ variation in the model. In the same way, to predict altruism, after controlling the effect of demographic variables and careerist orientation, coefficient of career growth opportunities was positive and statistically significant $\left(B=.57, \mathrm{p}<.01, \Delta \mathrm{R}^{2}=.25\right)$. Consequently, hypothesis 2.B was supported with contributing additional $25 \%$ variation in the model.

Moderation by career growth opportunities in the relationship of careerist orientation to conscientiousness and altruism was measured as procedure recommended by Barron and Kenny (1986). As shown in Table 2, Step 4, coefficient of interactive effect of careerist orientation and career growth opportunities to predict conscientiousness was statistically significant $(B=$ $\left..32, \mathrm{p}<.01, \Delta \mathrm{R}^{2}=.19\right)$. Therefore, hypothesis 3.A was supported with contributing additional $19 \%$ variation in the model due to interactive effect of careerist orientation and career growth opportunities. Similarly, to predict altruism, coefficient of interactive effect of careerist orientation and career growth opportunities was statistically significant $\left(B=.28, \mathrm{p}<.01, \Delta \mathrm{R}^{2}=\right.$ $.13)$. Hence, hypothesis 3.B was supported with contributing additional $13 \%$ variation in the model due to interactive effect of careerist orientation and career growth opportunities.

The significance of $\Delta \mathrm{R}^{2}$ in the model due to interaction of independent and dependent variable was used to measure the moderating effect of career growth opportunities in the direct relationships of careerist orientation to conscientiousness and altruism. But, the statistical significance of the change in $\mathrm{R}^{2}$ due to the addition of the interaction term is typically used as the criterion to measure the effect size of the interaction. However, Witt et al. (2000) argued that the change in $\mathrm{R}^{2}$ does not adequately reflect the magnitude of the impact of the moderator variable. As suggested by Witt et al., a limitation of using the change in $\mathrm{R}^{2}$ is: it only estimates of the average effect size of the interaction which is a conservative one. To address this issue, interactions were presented in graphs showing high (mean plus one standard deviation) and low (mean minus one standard deviation) value of interacting variable (Aiken \& West, 1991) 


\section{Table 2}

Regression Analysis: Direct and Interactive Association of Careerist Orientation and Career Growth Opportunities on Conscientiousness and Altruism

\begin{tabular}{|c|c|c|}
\hline \multirow{2}{*}{ Independent Variables } & \multicolumn{2}{|c|}{ Dependent variables } \\
\hline & Conscientiousness & Altruism \\
\hline \multicolumn{3}{|l|}{ Step 1} \\
\hline Sex & .01 & -.02 \\
\hline Age & -.05 & .17 \\
\hline Education & -.03 & -.09 \\
\hline Experience & -.14 & -.09 \\
\hline Tenure & .18 & .13 \\
\hline Designation & -.13 & -.01 \\
\hline$\Delta \mathrm{R}^{2}$ & .02 & .01 \\
\hline \multicolumn{3}{|l|}{ Step 2} \\
\hline Careerist orientation & $-.28 * *$ & $-.19 * *$ \\
\hline$\Delta \mathrm{R}^{2}$ & .07 & .03 \\
\hline \multicolumn{3}{|l|}{ Step 3} \\
\hline Career growth opportunities & $.53 * *$ & $.57 * *$ \\
\hline$\Delta \mathrm{R}^{2}$ & .27 & .25 \\
\hline \multicolumn{3}{|l|}{ Step 4} \\
\hline $\begin{array}{l}\text { Careerist orientation x Career growth } \\
\text { opportunities }\end{array}$ & $.32 * *$ & $.28 * *$ \\
\hline$\Delta \mathrm{R}^{2}$ & .19 & .13 \\
\hline
\end{tabular}

Note. ${ }^{* *}, *$, the mean difference is significant at the .01 , and .05 levels, respectively.

Figure 1 and Figure 2 display the graphic interaction of employees' careerist orientation and career growth opportunities on their conscientiousness and altruism. In figures, low value representing and high value representing moderator variable's graphic lines were not parallel; therefore, moderating role of career growth opportunities (Jose, 2008) tested by change in $\mathrm{R}^{2}$ was verified by graphic presentation. 


\section{Figure 1}

Moderation by Employees' Career Growth Opportunities in the Relationship between Careerist Orientation and Conscientiousness

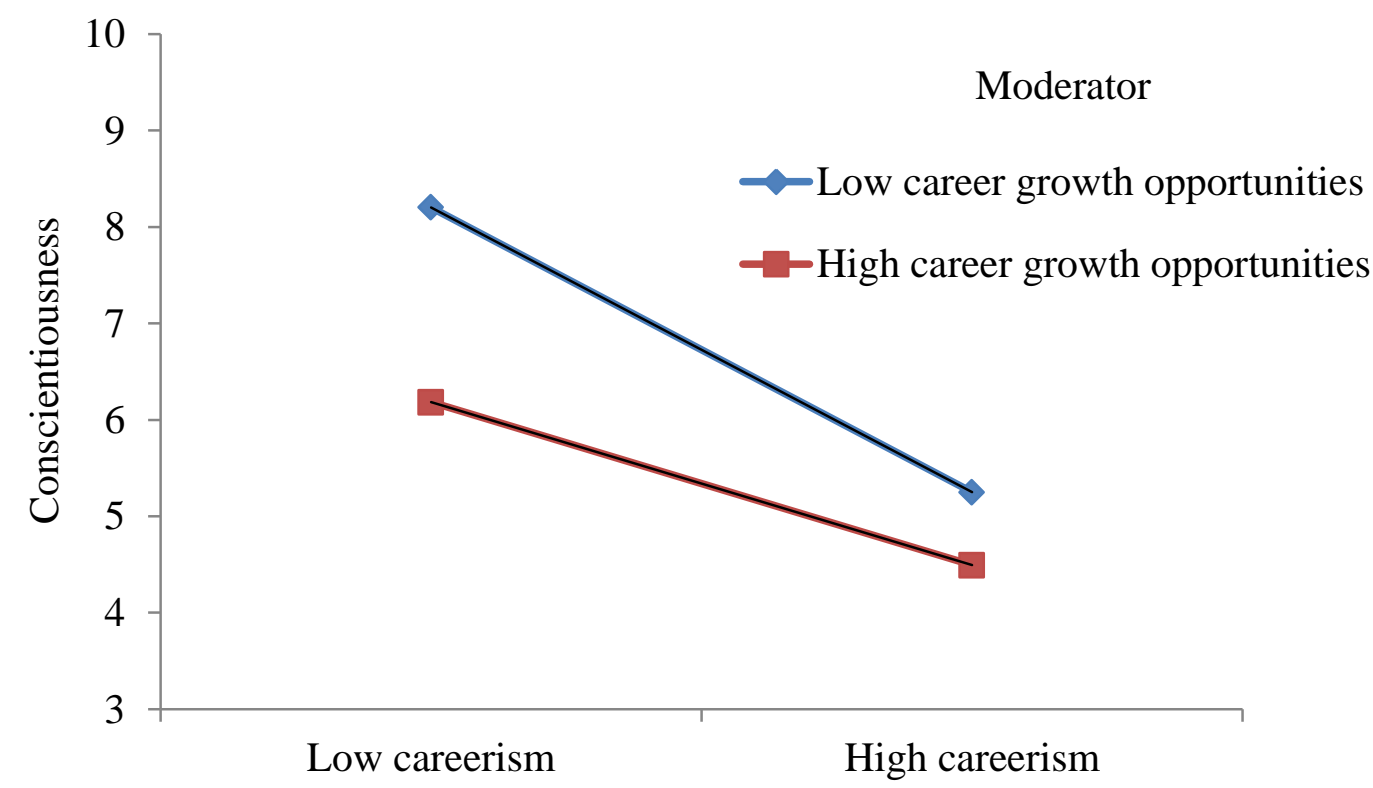

Figure 1 displays the graphic interaction of careerist orientation, career development opportunities and conscientiousness as independent, moderating, and dependent variables respectively. As shown in Figure 1, graphs representing the high and a low level of career growth opportunities were not parallel and sloped negatively. Career growth opportunities representing graphs were become less steep when it increased from low levels of career growth opportunities to high level of career growth opportunities. This indicates that career growth opportunity has buffering moderation in the relationships between careerist orientation and conscientiousness. Graph representing a low-value of career growth opportunities was comparatively steeper than high-value representing graphs. This indicated that there was a relatively strong marginal negative prediction of careerist orientation on conscientiousness for those employees who perceive a low level of career growth opportunities. In opposite order, there was a relatively weak marginal negative prediction of careerist orientation on the conscientiousness of those employees who had a high level of career growth opportunities.

Likewise, for the employee who has high level of careerist orientation, for them mitigating strength of career growth opportunities was nearly same whether they perceive high or low level of career growth opportunities, but difference in mitigating strength of high career 
growth opportunities and low career growth opportunities were increasing as decrease in level of careerist orientation. Moreover, as depicted in Figure 1, at a fixed point of careerist orientation (e.g. low level), the impact of careerist orientation on conscientiousness was better when there was a low level of career growth opportunities than the high level of career growth opportunities.

\section{Figure 2}

Moderation by Employees' Career Growth Opportunities in the Relationship between Careerist Orientation and Altruism

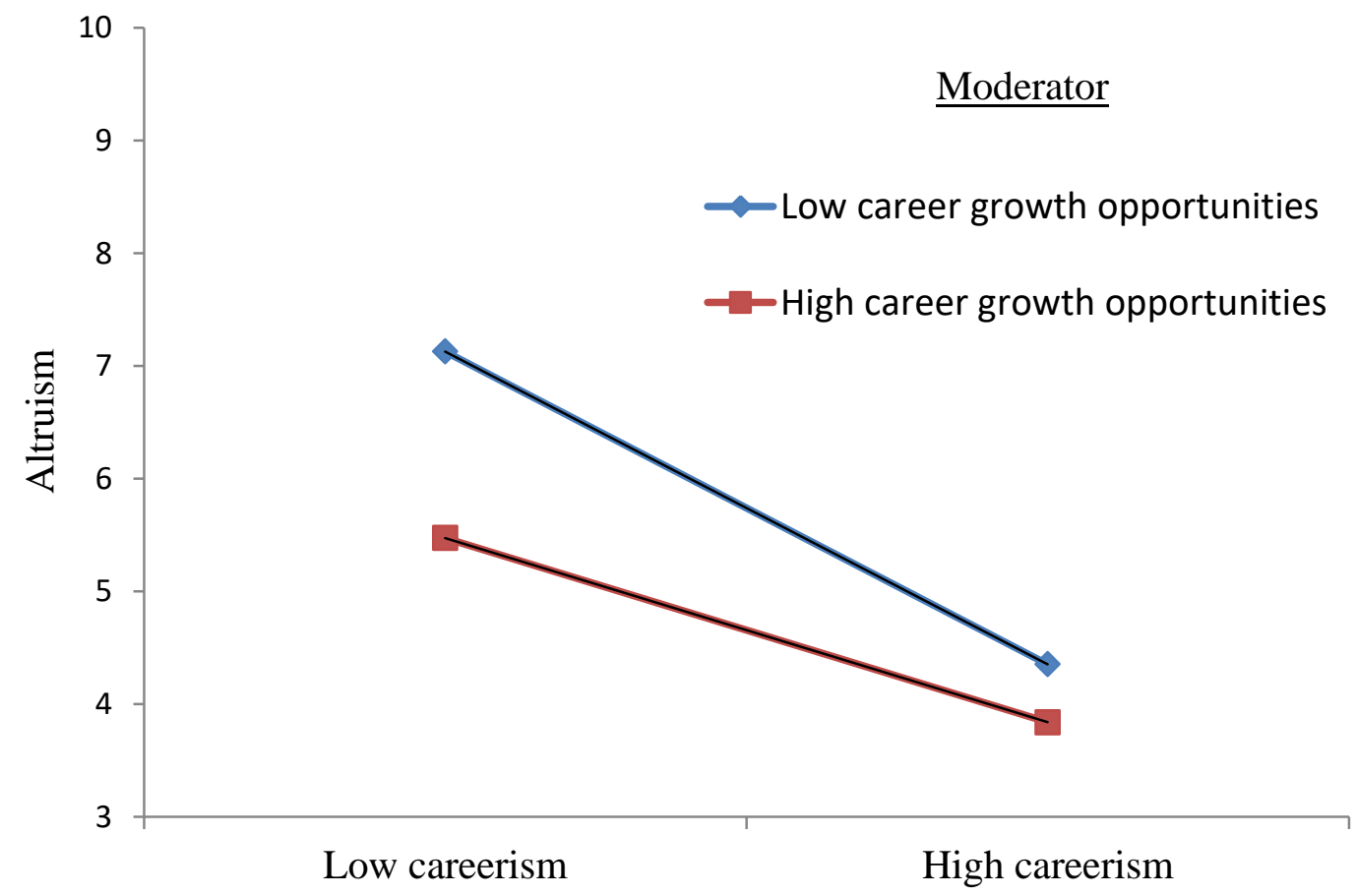

Figure 2 displays the graphic interaction of careerist orientation, career development opportunities and altruism as independent, moderating, and dependent variables respectively. As shown in Figure 1, graphs representing the high and a low level of career growth opportunities were not parallel and sloped negatively. Career growth opportunities representing graphs were become less steep when it increased from low levels of career growth opportunities to high levels of career growth opportunities. This indicates that career growth opportunity has buffering moderation in the relationships between careerist orientation and altruism. Graph representing a low-value of career growth opportunities was comparatively 
steeper than high-value representing graphs. This indicated that there was a relatively strong marginal negative prediction of careerist orientation on altruism for those employees who perceive a low level of career growth opportunities. In opposite order, there was a relatively weak marginal negative prediction of careerist orientation on the altruism of those employees who had a high level of career growth opportunities.

Likewise, for the employee who has high level of careerist orientation, for them mitigating strength of career growth opportunities was nearly same whether they perceive high or low level of career growth opportunities, but difference in mitigating strength of high career growth opportunities and low career growth opportunities were increasing as decrease in level of careerist orientation. Moreover, as depicted in Figure 1, at a fixed point of careerist orientation (e.g. low level), the impact of careerist orientation on altruism was better when there was a low level of career growth opportunities than high a level of career growth opportunities.

\section{Discussion}

As hypothesized, current study tested that employees' careerist orientation negatively impacts on employees' conscientiousness and altruism behaviour. This means an increase in level of employees careerist orientation cause to decrease in level of their conscientiousness and altruism behaviour. This finding consists with the explanation of social exchange theory (Balu, 1964) as well as empirical evidences of Chay and Aryee (1999), Feldman and Weitz, (1991), Liu and Wang (2001), and Ng et al. (2006) who have tested the negative impact of employees careerist orientation on employees' behavioral and attitudinal outcomes. In those studies tested constructs were not exactly same to the conscientiousness and altruism behaviour, therefore, further studies are suggested to replicate in different contexts with larger sized sample before generalizing the findings.

Likewise, as hypothesized, current study tested that employees perceived career growth opportunities positively effected on their conscientiousness and altruism behaviours. This indicates that employees' conscientiousness and altruism behaviour can be increased by increasing in their perceived career growth opportunities. Though there was not sufficient comparable prior empirical evidences, the finding of the current study consists with Weng and McElroy (2012) as well as Weng et al. (2010). As tested in current study it is natural human behaviour that employees do exhibit conscientiousness and altruism behaviours to impress employer where they see their career growth opportunities. However, we suggest carrying out future study in wide range covering different work environment as well as individuals to refine the theory.

Novel findings of the current study were different forms (effect sizes) of interactive effects of employees' careerist orientation and career growth opportunities to predict their organizational citizenship behaviours (conscientiousness and altruism). Firstly, it was tested 
that there was a relatively strong marginal negative prediction of careerist orientation on organizational citizenship behaviours (conscientiousness and altruism) for those employees who perceive a low level of career growth opportunities. This indicated that employees' organizational citizenship behaviours (conscientiousness and altruism) are seriously affects if they perceive less (even no) career growth opportunities, but such effects will be less for those employees who perceive good career growth opportunities in their current organization. Plausible causes for such impacts can be the employees' perception of job security and longterm working relationship with current employer. Employees whoever perceive good career growth opportunities in current organization they see own future inherent with organizational success; therefore, they do exhibit organizational citizenship behaviours (conscientiousness and altruism). Another, possible causes might be employees' self-core evaluation (Judge, et al., 1997) which deals about the individual's subconscious, bottom-line evaluations about oneself and evaluations about their abilities. Employees having high core self-evaluation might perceive that career growth opportunities, in the current organization, is within their own hand and to attain this they do discretionary activities for the organizational wellbeing like conscientiousness and altruism behaviors. Hence, we suggest carrying out further study controlling the effect of employees perceived job securities as well as their core self-evaluation to refine the findings and generalize theory.

Secondly, it was tested that employees who has high level of careerist orientation, for them mitigating strength of career growth opportunities was nearly same whether they perceive high or low level of career growth opportunities, but difference in mitigating strength of high career growth opportunities and low career growth opportunities were increasing as decrease in level of careerist orientation. This designates that highly careerist-oriented people are less effected that low careerist-oriented people due to change in low to high (or high to low) level of career growth opportunities. Plausible causes for this finding can be employees' degree of ambition, low careerist-oriented people are less ambitious and less ambitious people might be highly influenced (than highly ambitious people) by career growth opportunities and engage is discretionary behaviors like organizational citizenship behaviors (conscientiousness and altruism). Therefore, future studies will be more accurate if it is carried out taking consideration of employees' ambition while measuring the interactive effect of their careerist orientation and career growth opportunities. Thirdly, current study tested that, at a fixed point of careerist orientation (e.g. low level), the impact of careerist orientation on conscientiousness was better when there was a low level of career growth opportunities than a high level of career growth opportunities. This means at a given point of careerist orientation of the employees, organizational citizenship behaviours (conscientiousness and altruism) will be better (than those who perceive high career growth opportunities) for those employees who perceive less career growth opportunities. Possible causes for these findings can be employees' level of 
confidence, because when employees has no confidence that there are genuine chances of career growth opportunities in their organization, obliviously they don't keep them idle and might invest their time for extra role behaviours. Therefore, further study is suggested to carry out incorporating employees' level of confidence in their career growth opportunities offered by employer in the current organization.

\section{Practical Implication}

Firstly, employees' careerist orientation negatively affected their organizational citizenship behaviours (conscientiousness and altruism), therefore, managers should take corrective actions to minimizes the employee's careerist orientation so that their employee's organizational citizenship behaviours (conscientiousness and altruism) will be increased. Practically, the manager may organize career counseling to minimize employees' careerist orientation or make the replacement plan for highly careerist-oriented employees. Chiaburu et al. (2013) stated that employees' emotional stability negatively correlated with careerist orientation, but primary psychopathy and exchange ideology explained additional variance on careerist orientation. Therefore, by intervening in these areas, managers can improve employees' careerist orientation. Secondly, current study tested that positive relationship between employees' career growth opportunities and organizational citizenship behaviours (conscientiousness and altruism), therefore, managers can create and ensure different career development opportunities for current employees, for example, organization's vertical expansion strategies, product diversification strategies, adopting transparent and performancebased promotion policy etc. Thirdly, current study tested that employees' career growth opportunities cure the detrimental impact of their careerist orientation on organizational citizenship behaviours (conscientiousness and altruism). Beside numbers of efforts to remove employees' careerist orientation, it might be difficult to remove employees' careerist orientation, but the manager can lessen harmful effects by increasing their perceived career growth opportunities.

\section{Theoretical Implication}

Firstly, as current study verified the negative impacts of employee's careerist orientation as well as the positive impacts of their career growth opportunities on organizational citizenship behaviours (conscientiousness and altruism) in a unique context (i.e. employees working in Nepalese development projects), these findings add to the empirical evidences in the body of the knowledge which ultimately contributes to generalize the theories. Moreover, this theory can be tested in other context taking in consideration all the dimensions of the organizational citizenship behaviours as suggested by (Organ, 1988) like civic virtue, sportsmanship, Courtesy etc. so that literature will be more enrich with complete theory. Secondly, current study tested remedial role of employees' perceived career growth opportunities for the detrimental impact of their careerist orientation on organizational 
citizenship behaviours (conscientiousness and altruism). Putting steps in this finding, researchers may explore others possible antidotes (e.g. job security) to protect employees themselves as well as an organization form the harmful impacts of employees' careerist orientation. Regarding the remedial role of perceived career growth opportunities, more specific and novel findings are the forms of moderation (i.e. remedial power of career growth opportunities) under different situations of careerist orientation, for example, relatively strong marginal negative prediction of careerist orientation on organizational citizenship behaviours (conscientiousness and altruism) was measured for those employees who perceive a low level of career growth opportunities. In the literature of trading- off organizational interest and individual interest, such knowledge addition will be exciting for replication and extension of the study under different context so that proper theory will be developed. Beside replication, a researcher might divert their investigation that career growth opportunities can be a mediator, as suggested by Bashir et al. (2020), in the relationship of careerist orientation to organizational citizenship behaviours.

\section{References}

Adnan, N., Ahmad, M. H., \& Adnan, R., (2006). A comparative study on some methods for handling multicollinearity problems. Matematika, 22(2), 109-119.

Aiken, L. S., \& West, S. G. (1991). Multiple regression: Testing and interpreting interactions. Sage Publications, Inc.

Alvi, H. L., \& Ahmed, S. W. (1987). Assessing organizational commitment in a developing country: Pakistan- A case study. Human Relations, 40, 267-280.

Aryee, S., \& Chen, Z. X. (2004). Countering the trend toward careerist orientation in the age of downsizing. Test of a social exchange model. Journal of Business Research, 57, 321328.

Baron, R. M., \& Kenny, D. A. (1986). The moderator-mediator variable distinction in social psychological research: Conceptual, strategic, and statistical considerations. Journal of Personality and Social Psychology, 51 (6), 1173-1182.

Bashir, M. S., Haider, S., Asadullah, M. A., Ahmed, M., \& Sajjad, M. (2020). Moderated mediation between transformational leadership and organizational commitment: The role of procedural justice and career growth opportunities. Sage Open. https://doi.org/10.1177\%2F2158244020933336

Bateman, T. S., \& Organ, D. W. (1983). Job satisfaction and the good soldier: The relationship between affect and employee "citizenship." Academy of Management Journal, 26, 587-595.

Bedeian, A. G., Kemery, E. R., \& Pizzolatto, A. B. (1991). Career commitment and expected utility of present job as predictors of turnover intentions and turnover behavior. Journal of Vocational Behavior, 39, 331-343.

Blau, P. (1964). Exchange and power in social life. Wiley. 
Bolino, M. C. (1999). Citizenship and impression management: Good soldiers or good actors? The Academy of Management Review, 24(1), 8298. https://doi.org/10.2307/259038

Chay, Y. W., \& Aryee, S. (1999). Potential moderating influence of career growth opportunities on careerist orientation and work attitudes: Evidence of the protean career. Journal of Organizational Behavior, 20, 613-633.

Chiaburu, D. S., Muñoz, G. J., \& Gardner, R. G. (2013). How to spot a careerist early on: Psychopathy and exchange ideology as predictors of careerism. Journal of Business Ethics, 118(3), 473-486. https://doi.org/10.1007/s10551-012-1599-5

Cho, J. C., \& Lee, J. W. (2012). Performance management and trust in supervisors. Review of Public Personnel Administration, 32(3), 236-259. https://doi.org/10.1177/0734371X11421496.

Dysvik, A., \& Kuvaas, B. (2013). Perceived job autonomy and turnover intention: The moderating role of perceived supervisor support. European Journal of Work and Organizational Psychology, 22(5), 563-573. https://doi.org/10.1080/1359432X.2012.667215.

Feldman, D. C., Leana, C. R., \& Bolino, M. C. (2002). Underemployment and relative deprivation among re-employed executives. Journal of Occupational and Organizational Psychology, 75(4), 453471. https://doi.org/10.1348/096317902321119682

Feldman, D. C. (1985). The new careerism: Origins, tenets, and consequences. The Industrial Psychologist, 22, 39-44.

Feldman, D. C., \& Weitz, B. A. (1991). `From the invisible hand to the glad hand: Understanding a careerist orientation to work. Human Resource Management, 30, 237257.

Jose, P. E. (2008). ModGraph-I: A programme to compute cell means for the graphical display of moderational analyses: The internet version, Version 2.0. Wellington: Victoria University of Wellington. http://www.victoria.ac.nz/psyc/staff/paul-josefiles/modgraph/modgraph.php.

Judge, T. A., Locke, E. A., \& Durham, C. C. (1997). The dispositional causes of job satisfaction: A core evaluations approach. Research in Organizational Behavior, 19, $151-188$.

Karatepe, O. M. (2012). The effects of co-worker and perceived organizational support on hotel employee outcomes: The moderating role of job embeddedness. Journal of Hospitality and Tourism Research, 36, 495-516. https://doi.org/10.1177/1096348011413592.

Kiffin-Petersen, S., \& Cordery, J. L. (2003). Trust, individualism and job characteristics as predictors of employee preference for teamwork. International Journal Human Resource Management, 14, 93-116. 
Konovsky, M. A., \& S. Doug- L. P. (1994). Citizenship behavior and social exchange. Academy of Management Journal, 37, 656-669.

Lent, R. W., Brown, S. D., \& Hackett, G. (1994). Toward a unifying social cognitive theory of career and academic interest, choice, and performance [Monograph]. Journal of Vocational Behavior, 45, 79-122.

LePine, J. A., Erez, A., \& Johnson, D. E. (2002). The nature and dimensionality of organizational citizenship behavior: A critical review and meta-analysis. Journal of Applied Psychology, 87, 52-65.

Liu, X. P., \& Wang, Z. M. (2001). The study of organizational commitment and its development mechanism. Nankai Business Review, 4(6), 58-62.

Lo, M. C., \& Ramayah, T. (2009). Dimensionality of organizational citizenship behavior (OCB) in a multicultural society: The case of Malaysia. International Business Research,2(1)

Long, L. L., Fang, L. L., \& Ling, W. Q. (2002). Organizational career management: Measurement and its effects on employees' behavior and feelings in China. ActaPsychology Sinica, 24(1), 97-105.

Ng, T. W. H., Butts, M. M., Vandenberg, R. J., DeJoy, D. M., \& Wilson, M. G. (2006). Effects of management communication, opportunity for learning, and work schedule flexibility on organizational commitment. Journal of Vocational Behavior, 68(3), 474-489.

Nouri, H., \& Parker, R. J. (2013). Career growth opportunities and employee turnover intentions in public accounting firms. The British Accounting Review, 23, 1-11.

Nunnally, J. C., \& Bernstein, I. H. (2007). Psychometric Theory ( $3^{\text {rd }}$ ed.). New York, NY: McGraw Hill.

Organ, D. W. (1988). Organizational citizenship behavior: The good soldier syndrome. Lexington, MA: Lexington Books.

Paul, A. (2012). When you can safely ignore multicollinearity? Retrieved from: http://www.statisticalhorizons.com/multicollinearity

Podsakoff, N. P., Whiting, S. W., Podsakoff, P. M., \& Blume, B. D. (2009). Individual- and organizational-level consequences of organizational citizenship behaviors: A metaanalysis. Journal of Applied Psychology, 94, 122-141.

Podsakoff, P. M., MacKenzie, S. B., Moorman, R. H., \& Fetter, R. (1990). Transformational leader bational citizenship behaviors. The Leadership Quarterly, 1, 107-142. http://dx.doi.org/10.1016/1048-9843(90)90009-7

Podsakoff, P. M., MacKenzie, S. B., Paine, J. B., \& Bachrach, D. G. (2000). Organizational citizenship behaviors: A critical review of the theoretical and empirical literature and suggestions for future research. Journal of Management, 26, 513563.

Podsakoff, P. M., Scott B. MacKenzie, S. B., Lee, J. Y., \& N. P. Podsakoff (2003). Common method biases in behavioral research: A critical review of the literature and 
recommended remedies. Journal of Applied Psychology, 88 (5), 879-903.

https://doi.org/10.1037/0021-9010.88.5.879.

Richard, T. (2009). Qualitative versus quantitative methods: Understanding why qualitative methods are superior for criminology and criminal justice. Journal of Theoretical and Philosophical Criminology, 1 (1). http://jtpcrim.org/January_Articles/Qualitative_Vs_Quantitave_Richard_Tewksbury.pd $\mathrm{f}$.

Sullivan, S. E., \& Baruch, Y. (2009). Advances in career theory and research: A critical review and agenda for future exploration. Journal of Management, 35, 1542-1571.

Turnley, W. H., \& Feldman, D. C. (1999). The impact of psychological contract violations on exit, voice, loyalty and neglect. Human Relations, 52, 895-922.

Van, D. L., Jill, W. G., \& Richard, M. D. (1994). Organizational citizenship behavior: Construct redefinition, measurement, and validation. Academy of Management Journal, 37, 765-802.

Van Dyne, L., Graham, J. W., \& Dienesch, R. M. (1994). Organizational citizenship behavior: Construct redefinition, measurement, and validation. Academy of Management Journal, $37,765-802$.

Vande Griek, O. H., Clauson, M. G., \& Eby, L.T. (2020). Organizational career growth and proactivity: A typology for individual career development. Journal of Career Development, 1-14. https://doi.org/10.1177\%2F0894845318771216

Wang, Q., Weng, Q., McElroy, J. C., Ashkanasy, N. M., \& Lievens, F. (2014). Organizational career growth and subsequent voice behavior: The role of affective commitment and gender. Journal of Vocational Behavior, 84(3), 431-441.

Wang, Q., Weng, Q., McElroy, J. C., Ashkanasy, N. M., \& Lievens, F. (2014). Organizational career growth and subsequent voice behavior: The role of affective commitment and gender. Journal of Vocational Behavior, 84, 431-441.

Weng, Q. X., \& Hu, B. (2009). The structure of career growth and its impact on employees' turnover intention. Industrial Engineering and Management, 14(1), 14-21.

Weng, Q., \& McElroy, J. C. (2012). Organizational career growth, affective occupational commitment and turnover intentions. Journal of Vocational Behavior, 80, 256-265.

Weng, Q., \& Xi, Y. (2010). A literature review of employees' career growth. Forecasting, 6, $1-$ 7.

Weng, Q., McElroy, J. C., Morrow, P. C., \& Liu, R. (2010). The relationship between career growth and organizational commitment. Journal of Vocational Behavior, 77, 391-400.

Witt, L. A., Andrews, M. C., \& Kacmar, K. M. (2000). The role of participation in decisionmaking in the organizational politics-job satisfaction relationship. Human relation, 53(3), 341-358. https://doi.org/10.1177/0018726700533003. 


\section{Annex 1}

\section{Appendices}

Explorative Factor Analysis (Rotated Component Matrix)

Items/Factors Cons Alt $\mathrm{CO}$ CGO Another factor

\section{SET-A}

Always take extra breaks (Cons) R

Attendance at work is under the norms (Cons) $\mathrm{R}$

Believes in giving an honest day's work for an honest day's pay (Cons)

Does not obeys company rules and regulations even when no one is watching (Cons) $\mathrm{R}$

Does not helps others who have heavy work load (Alt) R

Helps orient new people even though it is not required (Alt)

Helps others who have been absent (Alt)

Is always ready to lend a helping hand to those around him/her (Alt)

Is one of the my most conscientious employees (Cons)

Willingly helps others who have work related problems (Alt)

\section{SET-B}

Being completely honest doesn't pay when dealing with your employer $(\mathrm{CO})$

Having a job assignment with high contact with superiors is more important to me than having a challenging job assignment $(\mathrm{CO})$

I believe that my present job has aided my growth in my career (CGO)

I feel that my present job will lead to future attainment of my career goals (CGO) 


\begin{tabular}{|c|c|c|c|c|c|}
\hline Items/Factors & Cons & Alt & $\mathrm{CO}$ & $\mathrm{CGO}$ & Another factor \\
\hline $\begin{array}{l}\text { It is easy to get ahead in an organization on sheer } \\
\text { merit alone }(\mathrm{CO}) \mathrm{R}\end{array}$ & & & .36 & & \\
\hline $\begin{array}{l}\text { My goals and my employer's goals probably will } \\
\text { not be compatible }(\mathrm{CO})\end{array}$ & & & .72 & & \\
\hline $\begin{array}{l}\text { My present job is not useful in achieving my career } \\
\text { goals (CGO) } R\end{array}$ & & & & .91 & 8 \\
\hline $\begin{array}{l}\text { My present job is relevant to growth and } \\
\text { development in my career (CGO) }\end{array}$ & & & & .89 & \\
\hline $\begin{array}{l}\text { Sometimes you have to act unethically to get the } \\
\text { promotions you feel you have coming to you }(\mathrm{CO})\end{array}$ & & & .89 & & \\
\hline $\begin{array}{l}\text { To get promoted, you need to do your job very well } \\
\text { (CO) (R) }\end{array}$ & & & .39 & & \\
\hline $\begin{array}{l}\text { When you go to work for a company, you have to } \\
\text { remember to watch out for yourself }(\mathrm{CO})\end{array}$ & & & & & .77 \\
\hline $\begin{array}{l}\text { Who you know is more important in an } \\
\text { organization that what you know }(\mathrm{CO})\end{array}$ & & & .67 & & \\
\hline $\begin{array}{l}\text { Working for my firm will not help my career } \\
\text { (CGO) R }\end{array}$ & & & & & .78 \\
\hline $\begin{array}{l}\text { You should be straightforward and honest in } \\
\text { dealing with your employer }(\mathrm{CO})(\mathrm{R})\end{array}$ & & & & & .93 \\
\hline
\end{tabular}

Extraction Method: Principal Component Analysis.

Rotation Method: Varimax with Kaiser Normalization.

Note: Cons. $=$ Conscientiousness, Alt $=$ Altruism, $\mathrm{CO}=$ Careerist orientation, $\mathrm{CGO}=$ Careerist growth opportunities

$\mathrm{R}=$ Reverse statement 